\title{
Almshouses in England and the Dutch Republic circa 1350-1800: A Comparative Perspective
}

I.

In May 1650 tragedy struck Sir John Conyers and his wife Maria de Pottere. Maria's nephew, Captain Henry Hume, an officer in the Dutch army, whom she had raised after the early death of her sister, died in the Dutch city of Delft, aged only 27. Maria de Pottere and Sir John had no children, nor, apparently, any other close heirs. Maria herself died less than two months later, in July 1650 , spending the remaining few months of her life, inter alia, on the construction of a splendid tomb for her parents and for her nephew in the parish church of Zierikzee, on the island of Schouwen. The town council gave permission for this elaborate funerary monument on 5 July 1650-ten days before Maria gave up the ghost, leaving completion of the tomb and construction and placement of two memorial slabs for herself and Henry to her aged husband, who did not follow her into the grave until he died, 72 years old, in 1658. With his own memorial slab attached, the tomb was now ready, an eloquent and resplendent memorial which would have lasted centuries were it not for the destructive fire in October 1832 which completely destroyed Zierikzee's medieval church.

However, Maria de Pottere and Sir John Conyers had not just wished to crown the earthly glory of their family-about to become extinct-with a splendid monument; they also spent a considerable amount of their capital on the construction of an almshouse in the village of Noordgouwe, close to Zierikzee, where the De Pottere family possessed landed estates. Maria and her husband had lived there themselves, in a small castle. Unlike their splendid tomb, this almshouse, called the Conyershuisjes or the Pottershofje, has survived until the present day, still bearing evidence of their charity and still bringing to local memory their name, as no doubt was their intention.

What Maria and Sir John did after their bereavement was a not unusual phenomenon. Although the form of charitable endowments differed through time and by place, for this seventeenth-century couple the choice of an

Address correspondence to Nigel Goose, School of Humanities, University of Hertfordshire, Hatfield, Hertfordshire AL10 9AB.

Journal of Social History vol. 45 no. 4 (2012), pp. 1049-1073

doi:10.1093/jsh/shr146

(C) The Author 2012. Published by Oxford University Press. All rights reserved.

For permissions, please e-mail: journals.permissions@oup.com. 
almshouse was obvious. Both came from cultures in which the founding of almshouses was a recurring feature of charitable initiative. Maria de Pottere's family originally came from the Southern Netherlands, where there were many almshouses in the cities; it was no different in the north, where the family settled to preserve its Protestant conviction. Sir John Conyers was an Englishman, a Royalist exile in the Netherlands, and almshouses were also a common feature of the charitable landscape in England. ${ }^{1}$ So common were they in each country, in fact, that this Anglo-Dutch couple would have had no difficulty, whatever cultural differences there may have been between them, in recognising in the almshouse a mode of charity familiar to them both.

Welfare regimes in early modern Europe conformed to no simple pattern along denominational lines, as Natalie Zemon Davis showed us long ago. In Lyon the Aumône-Générale-a city-wide programme of poor relief administered by the lay authorities-persisted through both Catholic and Protestant control of the city. ${ }^{2}$ On a national level it is no easier to determine the shape that welfare programmes might have taken by simple reference to religious allegiance, for even in Spain, where begging received greater toleration than elsewhere, the vagrant poor might be whipped or even hung. ${ }^{3}$ But despite the variety that can be found within individual countries, and the fact that similarities can be found across national boundaries, national welfare regimes were not the same, and one in particular stands out from the rest. Historians of European social welfare have repeatedly emphasised the unique nature of the English poor law system by the seventeenth century, with its statutory provision and implementation of poor relief financed from taxation. ${ }^{4}$ The situation in the Dutch Republic was very different indeed, with private and voluntary donations providing the financial basis of the entire welfare system, which, in most of the Republic, was organised on a local, rather than a provincial or national, level. ${ }^{5}$ But despite this fundamental contrast the two nations shared similarities which should not be overlooked. As we will show, an almshouse in England was unlikely to differ much from an almshouse in the Dutch Republic with regards to its essential characteristics, which suggests that the charitable landscape in both countries had more in common than accepted orthodoxy suggests. The endurance of these institutions across several centuries also represents a degree of continuity between the medieval and early modern periods in each country, and shows an abiding concern to provide succour to the impotent, elderly (and usually local) pooracross the divide created by both humanist social theory and the Reformationeven as attitudes towards the idle and the dissolute hardened. In terms of the relative importance of these institutions, however, the two nations had clearly diverged by the start of the eighteenth century.

II.

Almshouses have not been subjected to extensive scholarly attention in either country. In England, the almshouse remains a sadly ignored facet of the mixed economy of welfare. Apart from popular publications, so often dominated by photographs and bereft of serious historical context, it is hard to find a detailed, academic study of these institutions. ${ }^{6}$ The situation in the Netherlands is similar, where institutional care has attracted only selective attention, mainly focused upon orphanages or particular medical hospitals. ${ }^{7}$ This neglect in both 
countries has led, independently, to projects designed to increase and improve scholarly knowledge of the phenomenon. ${ }^{8}$ Both intend to produce, in the first instance, a body of empirical information on the almshouses that existed between the later medieval period and the nineteenth century, to form a basis for deeper study of this neglected institution and, in due course, to facilitate an understanding of their place within the broader context of social welfare in the respective countries. But the two projects have another long-term aim in common, and this is to create opportunities for international comparisons.

\section{III.}

Defining an almshouse is far from straightforward, for pre-modern institutions of social care did not always have clear-cut boundaries, and their precise purpose was shrouded in terminological confusion. In England institutions providing either care or accommodation for the poor and the sick were described as lazar houses, spitalhouses, bedehouses, Godshouses, maisondieu, hospitals and a range of other descriptors, as well as almshouses. ${ }^{9}$ It is often difficult to clearly establish their function, for many served a number of purposes, and had not yet evolved into the residences for the (usually) elderly poor that is the modern characteristic of an almshouse. In the Netherlands we find a similar array of, often interchangeable, names to describe almshouses, which differed from region to region as well as over time-gasthuis, kameren, godskameren, godshuis, weduwenhuis, provenhuis, aalmoeshuis and hofje, the latter having now become the most common descriptor, equivalent to the English term almshouse. ${ }^{10}$ Another complication was the changing use of institutions. The hospitals of St Mary Magdalene and St Catherine's in Lexden, Colchester, both survived the Reformation. Part of St Catherine's appears to have been converted to a private house and garden by 1545, but the major part survived into the seventeenth century as a hospital or almshouse until its conversion to a workhouse in the eighteenth century. ${ }^{11}$ Similarly in the Netherlands some smaller hospitals developed into almshouses, as in the case of the Stappenhuis or Stappenconvent in Deventer, founded in 1342 by the canon Henricus Stappe for beguines, which became an almshouse for elderly unmarried women after the Reformation. ${ }^{12}$

In both countries, almshouses must be distinguished from other institutional arrangements for the elderly poor. In England, during the eighteenth century, and probably before, local parish vestries sometimes provided accommodation for their poor, elderly or not, in "poor houses," while church houses - initially established to provide a meeting place and accommodation for church alescould also be adapted to house the poor. Both of these co-existed with privately-endowed almshouses. ${ }^{13}$ In the Dutch Republic old men's homes ("oudemannenhuis") and old women's homes ("oudevrouwenhuis"), usually founded by City governments or the Dutch Reformed Church, provided for elderly burghers of modest means who were unable to look after themselves. ${ }^{14}$ The Dutch Republic, in some places, also knew poorhouses, which might shelter the elderly poor along with other age-groups. But distinguishing private institutions from these public ones is not always a simple matter, and further confusion can be added when local authorities stepped in to save a hitherto private institution from dissolution, either by providing funding or by taking over its administration from the originally designated trustees. For example, in 
early modern Colchester ailing charities were supported in the seventeenth century from Corporation funds, including John Hunwick's substantial bequest of $£ 300$ made in 1594, which required regular Corporation subsidy by the 1640s. ${ }^{15}$ Similar cases where local authorities assumed responsibility can be found in the Netherlands: in Zierikzee, for example, the St Jacob's Guild of Seafarers had founded an almshouse before 1472-the St Jacobshofje-which had to be taken over by the city authorities in $1580 .{ }^{16}$ The distinction between public and private could also be blurred intentionally: in Haarlem in the Netherlands, for example, the Hofje van Gratie, founded in 1554 by the private founders Ghijsbrecht van der Mollen en Willem Diert, was transferred by the founders to the burgomasters of the city who, however, appointed regents to look after the foundation. ${ }^{17}$ In England the will of William Doughty in 1687, which established the almshouse in Norwich that bears his name, made specific provision for the town's Corporation to assume responsibility for the institution after a designated number of years, a transition that caused considerable controversy. ${ }^{18}$

It is therefore important to define the precise nature of the institutions to which we are referring in this article. Our subject matter is those institutions specifically designed to provide accommodation for the elderly poor, whether established by an ecclesiastical foundation, a monarch or member of the ecclesiastical hierarchy, by a company or by a private individual of whatever status. Their purpose was to provide free, sheltered accommodation for elderly people of modest means, usually in discrete apartments within a larger edifice, which may or may not have been supplemented by additional benefits in the form of a weekly stipend and allotments of food, clothing or fuel. While local authorities might sometimes have intervened in the life of these institutions, and the state may have become increasingly involved in their regulation, their defining characteristic is their provenance in the realm of philanthropy, whether founded by a private person or by an organisation. ${ }^{19}$

IV.

Despite the radically different poor law regimes in these two countries, comparison of Dutch and English almshouses reveals many similarities, in terms of architecture, their origins and development, the pace of foundation, the social status of founders, geographical spread, number and status of inhabitants and forms of administration.

Turning first to architecture, while considerable variety existed in both nations, there were four main forms: the hall, the courtyard, the terrace or row, and the house. In England the medieval, monastic antecedents of the almshouse-the "farmery" or infirmary-commonly took the form of a great hall, with separate bed spaces provided along the walls, connected to a chapel and possibly also a kitchen, hence usually offering only limited privacy to residents. Similar hall and chapel designs were found on the continent, Sint Jan's Hospitaal in Bruges providing a classic example. ${ }^{20}$ In the Netherlands one such hall-like hospital has survived, the Sint-Pietersgasthuis in Amersfoort, and most early foundations started out as this type. ${ }^{21}$ This form could also be found in some later almshouses, which had often started out as undifferentiated hospitals before specialising in care for the elderly. 
From the later Middle Ages in England the courtyard design, or almshouse-in-court, creating greater opportunity for both individual and communal privacy, became more common in both countries. In this form, separate units of accommodation were arranged around a central courtyard, with an archway or gate providing ingress and egress, often with a separate residence for the almshouse master within the gatehouse, and a central well, a coalhouse or other facilities located in the courtyard itself. ${ }^{22}$ The grander almshouses which took this form had additional features, such as Greenwich Trinity Hospital near London, which also included a cloister walk, a chapel, a kitchen and scullery, and lodgings for a butler, with the warden or master being accommodated on the first floor. ${ }^{23}$ In the Netherlands this form-known there as the "hofje," or "small court"- has become the archetypal form of an almshouse, and was identical to the English courtyard design with central facilities that might also include a bleaching field, and a separate apartment or "regentenkamer" ("regent chamber") where the almshouse regents would meet to discuss its affairs, and perhaps also house portraits and memorabilia of its founder. ${ }^{24}$

Smaller almshouses more commonly took the form of a terrace or row. In England these were probably the most common and enduring form from the sixteenth century forwards. Generally lacking a chapel, communal areas or accommodation for staff, they often included small gardens for the use of the residents. These rows were also found in the Dutch Republic, for example in Utrecht, where most almshouses were of this type. ${ }^{25}$ The almshouse founded by Maria de Pottere and Sir John Conyers in Noordgouwe is also built in a row. Finally, very small almshouses in both countries might take the form of a single house, divided up into discrete units of accommodation, while combinations of these basic forms can also be found, as well as variations upon these themes resulting from subsequent extension or expansion in the capacity of the individual units they contained.

There are also remarkable similarities in the origins and development of almshouses in the two countries. In both they developed, at least partly, from hospitals that provided care for the sick poor, usually attached to a monastery, whose obligation to distribute alms was clearly established at the Synod of Aix in 816 A.D. Alms were often distributed at monastery gates, but gradually the practice of providing board and lodging for travellers became more common, while aged and sick monks were also cared for on-site in a "farmery." During the twelfth and thirteenth centuries these two practices were often merged, as monasteries began to minister also to lay people who were sick or feeble, though most commonly this took place in separate establishments administered by the monks and lay brethren. Lazar houses specifically for lepers existed alongside these monastic institutions, while in both countries hospitals for the sick poor more generally were, from the thirteenth century, increasingly founded by nonmonastic benefactors- the crown, senior clergymen, the aristocracy and gentry, and urban livery companies and guilds or individual wealthy merchants. ${ }^{26}$ Lay provision gradually assumed greater importance in both England and the Netherlands, although monastic hospitals continued to function alongside the growing number of lay institutions, and monasteries continued to provide sizeable sums to relieve the poor. In both countries the later medieval period witnessed the flowering of almshouses in their modern form, specifically intended to provide accommodation for local, elderly people who had fallen into poverty 
on account of age or ill-health. Thus the complex array of English and Dutch institutions that were to evolve into almshouses originated in Catholic, monastic houses.

Further similarity is evident in terms of the pace of foundations in the two nations, and in the relationship between economic development and the number of foundations over both time and space. Following an acceleration of foundations in the fifteenth century, English endowed institutions suffered badly through the depredations associated with the English Reformation. The monasteries and their associated charitable institutions were swept away in 1536 and 1539, while in 1545 and 1547 the crown also confiscated the property of chantries, some hospitals and some parish religious fraternities. ${ }^{27}$ Between 1536 and 1549, McIntosh has estimated, some 260 hospitals and endowed almshouses were closed, representing at least half of the existing institutions. ${ }^{28}$ Thereafter recovery ensued, with 479 institutions continuing in operation at the end of the sixteenth century. ${ }^{29}$

Dutch almshouse foundations also increased in number over time, from 18 in the fourteenth century, 44 in the fifteenth, and 66 in the sixteenth, although here the impact of the Reformation awaits detailed exploration. It was the seventeenth century, however, that witnessed the most concerted growth in the number of almshouses in both countries, and this corresponds with their achievement of commercial supremacy on the European-indeed worldstage. ${ }^{30}$ For England, Jordan's monumental study of philanthropy in ten counties suggests that a little over 10 per cent of all parishes included an almshouse by 1660, which-if his sample can be regarded as representative-would equate to a total in the region of 1,000 nationally. ${ }^{31}$ The pace of foundations in the Dutch Republic also accelerated in the seventeenth century, with 133 new foundations, more than double the total of the previous century. By contrast, in the eighteenth century only 60 new almshouses were founded, which suggests that the general decline of the Dutch economy contributed also to a decline in almshouse foundations. ${ }^{32}$ In England, however, only during the French Wars (1789-1815) does there appear to have been a falling off in almshouse construction, while the prosperous Victorian era witnessed a renewed spate of foundations. ${ }^{33}$

Regional variations are evident in both countries too, and can again be at least loosely associated with economic strength in general and levels of urbanisation in particular. In the Dutch Republic, the highly urbanised Province of Holland dominated over the rest, with a total of 219 foundations before 1800 compared with just 225 for the rest of the country. Within Holland, the wealthy cities of Haarlem, Amsterdam and Leiden led the rankings, with 54, 45 and 41 foundations respectively. The poor, largely rural inland Province of Drenthe, by contrast, produced not a single foundation. In England Jordan's data reveals the dominance of London, and the prominence of provincial cities such as Bristol in terms of philanthropic endowments, while the relatively poor and weakly urbanised county of Lancashire spent very little at all on almshouse foundation. In England and Wales as a whole the long-term impact of medieval and early modern economic strength and levels of urbanisation persisted through to the third quarter of the nineteenth century, when counties such as Cornwall, Cheshire, Durham, Lancashire, Staffordshire and much of Wales remained very poorly endowed with almshouses. ${ }^{34}$ 
While founders came from a variety of social strata, a certain minimum level of wealth was needed if provision for the long-term maintenance of an institution was to be established, without which an almshouse's existence could be very precarious. ${ }^{35}$ In England they varied from kings, archbishops and aristocracy down to relatively humble merchants and tradesmen. London livery companies became increasingly involved from the fourteenth century, often restricting potential applicants to their own membership, while secular almshouses in general became more common from the late fourteenth century. ${ }^{36}$ In the Netherlands too they ranged across the social scale, from the Counts and Dukes who ruled the Netherlandic principalities down to more humble but wealthy merchants. Just as in England, the religious and political hierarchy took the lead, with increasing numbers of private individuals becoming involved from the mid fourteenth century forwards. Others, however, were founded by private organisations, such as guilds and the deaconries of Mennonite congregations in Amsterdam, Haarlem and Leiden, all of which built one or more almshouses.

It is too early to do more than sketch a profile of an almshouse founder. For the Dutch Republic, analysis of the 342 almshouse founders who currently feature in the DAD reveals that the vast majority, as one would expect, were of fairly high status. In terms of personal characteristics, out of the 238 whose religion could be identified 159 were Catholic and 37 Dutch Reformed in religion, although the adoption of an arbitrary date of 1572 for the onset of the Reformation, and the assumption that everyone before that date was Catholic, must clearly influence these figures. As for gender, of the 342 individual founders 155 were men and 83 were women, with 62 male/female co-founders. Of 169 whose marital status could be identified to date, 86 were married, 43 were widowed and 40 had never married at all. They were also likely not to have children, though concrete statistics with regard to childlessness are not available yet. No similarly detailed personal information is as yet available for England, although a preliminary analysis of the almshouse data collected to date also indicates the dominance of men, and-allied to evidence from London-suggests that there too the lack of heirs may have been a factor that encouraged philanthropic endowments, either as an alternative means to memorialise the family name or simply because there was no-one suitable to bequeath wealth to. ${ }^{37}$

Whatever their architectural form, where they were located, when they were founded and by whom, most almshouses in both countries were relatively small institutions. In English almshouses the number of inhabitants averaged perhaps $8-10$ residents, while in both countries in the fifteenth and sixteenth centuries twelve and thirteen were popular numbers, standing for the twelve Apostles with or without Christ. ${ }^{38}$ Of course, some were smaller and a few much larger, and again examples can be found in each country. In the Dutch Republic the Hofje van Nieuwkoop in The Hague was exceptionally large, boasting 60 apartments and able to accommodate double that number of inhabitants, while the Hofje Gerrit de Koker in Rotterdam, founded in 1784, could accommodate 72 people. In England the royal hospitals were among the largest, the Royal Naval Hospital for retired seamen at Greenwich taking in 350 by 1708, while the Royal Hospital at Chelsea took in as many as 500 veteran soldiers when it opened its doors in $1692 .{ }^{39}$ These were, however, quite exceptional, most almshouses in both countries being quite modest in size and capacity. It seems that, at least in the Dutch Republic, the number of inhabitants increased over 
time: new almshouses founded in the seventeenth and eighteenth centuries offered places to a much greater number of inhabitants than earlier foundations, but, overall, most almshouses in the DAD did not exceed ten inhabitants.

The social background of almshouse residents was also strikingly similar in the two countries, for in neither were they generally drawn from the very lowest class. Some were reserved for dedicated groups, whether of a particular religious affiliation, former household retainers or members of specific occupations or companies. In the Netherlands, aside from the occasional elite inhabitant who had hit on hard times, most inhabitants of almshouses seem to have come from the respectable middle and lower middle classes, for whom a place in an almshouse meant an honourable way of avoiding the combination of elderly physical decline and dishonourable public poverty. In England, while again there are occasional examples of places being reserved for those of noble birth in their declining years, ${ }^{40}$ most almshouses showed a similar preference for the "respectable poor." The medieval practice of granting corrodies, such as at St Wulston's Hospital in Worcester, required the equivalent of an entrance fee, and hence immediately disqualified those who were very poor. ${ }^{41}$ These have their equivalent in the "proveniers" or corrodians found in the Dutch Republic. Sometimes it was stipulated that entrants had to bring their own household furnishings with them, which would again have a socially selective effect. When in 1434 Henry Barton left various properties to the Skinners' Company for conversion to residencies for the poor, he specifically stated that they were to be reserved for men and women who had previously maintained homes and families but who had come down in the world, not common beggars. ${ }^{42}$ At Ewelme in Oxfordshire, the fifteenth-century statutes specifically exclude lepers, madmen or those with infectious diseases or intolerable sickness, while allowing residents a combined income from the almshouse endowment and personal wealth of between $£ 4$ and $£ 5$, which would probably place them among the husbandman or artisan classes. ${ }^{43}$ A survey of a sample of 7,655 nineteenth-century almshouse residents in nine English counties, 2,804 of whom were identified by occupation, shows that a very wide range of occupations was represented. Among men, while agricultural labourer (or simply "labourer") was the most common occupation, these were outnumbered overall by various trades and craftsmen. Among women, while servants, nurses and dressmakers lead the rankings, housekeepers, governesses, schoolmistresses and milliners are found in numbers too. ${ }^{4}$

Apart from an insistence that almshouse applicants should be respectable and god-fearing, there were usually also requirements relating to age and place of residence. In the nineteenth-century English sample just referred to, the median age was 70, while the mean was a little lower at 64 due to the presence of a small cluster of younger girls and women. In Warwickshire, almost all almshouse residents found in the 1851 and 1881 censuses were aged 60 or over. ${ }^{45}$ Sixty, it seems, appears to have been generally regarded as indicating the onset of "old age" by the Victorian period, although age qualifications as low as 50 can also be found for individual almshouses, particularly in earlier centuries. ${ }^{46}$ Rules on the age of new applicants could also change over time. For example, in his will William Doughty of Norwich stipulated that no-one 60 years or younger was to be admitted to his almshouse, a rule which appears to have been followed faithfully up to the mid nineteenth century. In 1856 , however, it was decided by the trustees that the minimum age limit for nomination should be raised, and from 
that date no candidate under 65 years old was to be accepted into the hospital. ${ }^{47}$

In the Netherlands, age requirements, though subject to variation from one almshouse to the other, gradually rose over the centuries. In the oldest almshouses, such as those founded in Bois-le-Duc in the late Middle Ages, a minimum age could vary from 30 to 40 . Thirty years was in fact very young, and most almshouse founders seem to have believed a higher figure was more appropriate, most Dutch almshouses adopting an age at entry of either 50 or 60 throughout the early modern era, with a few choosing 55 years. The earliest almshouse to fix entry age at 50 was the Geertruids- and Pepergasthuis in Groningen, founded in 1405; the earliest almshouse to put it at 60 was the Hofje van Bakenes in Haarlem, founded in 1395. Higher entry ages were very uncommon: the only almshouse to put it at 70 was the Heilige Geesthofje in The Hague, founded in 1616. At the other extreme, the Hofje van Torenburg in Alkmaar, founded in 1689, instituted a minimum age of 35 years. But 50 or 60 remained the general rule, and this remained so throughout the nineteenth century; not until the late nineteenth century did new foundations fix the minimum age at 75 .

Residential requirements were also common in each country. Just as landed families would provide for their own household staff and retainers, the majority of English almshouses specified that applicants should come from the same parish or town, or from a carefully circumscribed local area. Almshouses in general were thus very strongly associated with place, and hence philanthropy mirrored the essentially parochial basis of the English system of poor relief that evolved during the sixteenth century. This is perhaps unsurprising, as almshouses as defined here formed part of the developing parochial system of social welfare of the later Middle Ages, with its mix of individual charitable giving, clerical or monastic help, support from lay fraternities or guilds, manorial assistance, and in some instances the provision of almshouses too. ${ }^{48}$ Of course there were again exceptions, particularly for those specialised almshouses that catered for specific occupational groups, such as retired soldiers or seamen. ${ }^{49}$ Other exceptions can also be found. In the nineteenth-century Derby Poor Law Union only one of the four almshouses enforced a strict residential requirement; one of the others was dedicated to clergy widows, while the almshouses founded by the Countess of Shrewsbury and Robert Wilmott favoured inmates connected with the families of the founders, but who may or may not have lived in the immediate locality. ${ }^{50}$ Residential requirements seem to have been a little less important in the Dutch Republic, founders often having a preoccupation for preferring their relatives over non-relatives and their fellow-believers over followers of different creeds, but residential requirements can be found in a many almshouses too. Usually only those born or living in the locality where the almshouses was founded were eligible, but there were exceptions to that rule. For example the Heilig Geesthofje in Naaldwijk, refounded in 1627 by stadholder Frederick Henry, catered for inhabitants from his lordships of Naaldwijk, Honselaarsdijk, Monster, Poeldijk, Wateringen, Ter Heide and Loosduinen. ${ }^{51}$ Generally, in practice if not in theory, most Dutch almshouses recruited their inhabitants from a restricted geographical area.

Finally, in terms of almshouse management, the two countries again exhibit similar arrangements, the boards of trustees in England corresponding to the 
boards of regents of the Netherlands. Both were usually selected by co-option, but some ended up being supervised or even governed by religious or civic organisations, as in the English example of Doughty's Hospital in Norwich, discussed above. ${ }^{52}$ Here controversy arose in the 1830s when aldermen were accused of buying votes through the promise of almshouse places, eventually resulting in the establishment of a new body of trustees that was at least partly independent of the town Corporation. ${ }^{53}$ Some almshouses, however, effectively functioned as family affairs, without a proper board of trustees or regents. This was particularly true of those institutions that were either reserved for, or gave preference to, their founder's household staff, such as that founded at Arundel, Sussex, by the Earl of Arundel, Lady Hungerford's almshouse founded at Heytesbury in 1472 and that founded by Antony baron van Haersolte van Elsen in Zwolle, sometime before $1671 .{ }^{54}$ There were almshouses where the descendants would regard membership of the board as a right, and did not hesitate to enforce their rights if other family lines attempted to usurp their place on the board. ${ }^{55}$ Occasionally these almshouses were transferred from family control to other private organisations, as with the St Andrieshofje in Amsterdam, founded in 1617 by the Oly family and run by the family until their extinction in 1699, when the administration transferred to the Catholic deaconry. ${ }^{56}$ Again, the variety is a shared one and transcends the maritime border between England and the Netherlands.

V.

In many respects, therefore, almshouses were remarkably similar in England and the Dutch Republic. There were, however, some notable differences, the first of which is their great rarity in rural areas in the Netherlands. Indeed, of the 425 almshouses founded before 1800 included in the DAD, a mere 11 (2.6 per cent) were located in villages. ${ }^{57}$ Most of these village-based almshouses were situated in Friesland, while on the Zeeland island of Schouwen two out of five were rural, the other three being situated in the capital Zierikzee. Furthermore, even these few rural almshouses were frequently endowed by urban benefactors. ${ }^{58}$ The heavily urbanised Province of Holland in particular, and the cities of the western seaboard more generally, were, as already noted, particularly favoured with almshouses. In England, by contrast, while the largest establishments were generally located in cities and towns, and a majority of the total number identified by McIntosh for the period 1350-1600 were in communities of the status of a market town or above, fully 29 per cent of the total was situated in village locations. ${ }^{59}$ The data extracted from the Victorian Digests of endowed charities tell a similar story, for despite the prominence of almshouses in so many towns there were considerable numbers also located in the English countryside. Furthermore, despite the undeniable prominence of the mercantile classes of London and the larger provincial cities in charitable activity, outside of the capital many of the counties which exhibited a relatively high percentage of localities that could boast an almshouse were notably lacking in large towns, including Berkshire, Buckinghamshire, Hertfordshire, Rutland and Surrey. ${ }^{60}$

Another contrast lies in the gender balance of almshouse residents. In the Dutch Republic, as in England, some almshouses were reserved for elderly men, some for women, while others admitted both. ${ }^{61}$ In the former, however, an 
overwhelming majority of the almshouses identified to date were reserved for women: either women who had never married, or women who had been widowed and for a variety of reasons did not, or could not, live with their offspring. This meant in practice that most almshouses focused on providing housing for elderly women, although the other categories of inmate never wholly disappeared. For 212 out of 425 almshouses founded before 1800 their gender requirements are known: 37 allowed both men and women, just 21 were for men, but 154 were reserved strictly for women. Moreover, the almshouses for men and couples were, as a rule, founded in the late Middle Ages or towards the start of the early modern period, and hence Netherlands' almshouses assumed their characteristic female gender bias at an early date.

In late medieval and early modern England, in contrast, the balance was weighted towards men. In the 1,005 almshouses identified by McIntosh for the period 1350-1600, 34 per cent of places were allocated to men only, 24 per cent to women only, and 42 per cent were available to both sexes. If we assume an equal distribution of men and women among the unspecified group, the sex ratio of almshouse occupancy 1350-1600, expressed in the conventional manner of males per 100 females, stands at 122: in other words, 55 per cent of places were available to men, and only 45 per cent to women. By the second half of the nineteenth century, however, this balance had changed fundamentally. The interim results from the English Almshouse Project, drawing upon census information from 1841 to 1901, shows that of the 7,648 permanent almshouse residents in the sample whose sex could be identified, fully 5,697 were female and just 1,951 were men, producing a sex ratio of 34 (men per 100 women): in other words, by now 74 per cent were female. In the nineteenth century, however, while women predominated in almshouses everywhere, this was far more marked in London than it was, for instance, in East Anglia, suggesting the possibility of a gendered geography of almshouse residency. Hence while the sex ratio for Middlesex stood as low as 21, for Suffolk it stood at 47 and for Norfolk $54 .{ }^{62}$ This changing gender balance in English almshouses over time is a recent discovery: its timing - and the demographic, social, economic and cultural factors that lay behind it-remain to be fully explored.

Another contrast between almshouses in England and the Dutch Republic lies in the number of occupationally-specific institutions found in England, and their rarity in the Netherlands. Institutions dedicated to the clergy in England appeared relatively early, in the thirteenth and first half of the fourteenth centuries when competition for benefices was fierce, leaving many unbeneficed domestic chaplains or curates in a particularly vulnerable position. ${ }^{63}$ Although the need and the demand for places declined after the Black Death of 1348-9, such institutions did not disappear, some reinventing themselves as institutions dedicated to clergy widows, like the Derbyshire example cited above. ${ }^{64}$ Almshouses dedicated to specific crafts and trades emerged during the later Middle Ages, as we have already noted, often founded by London livery companies, such as the Vintners in 1357, the Merchant Tailors circa 1404, the Grocers about 1429 and the Drapers in $1521 .^{65}$ Their continuing impact had been emphasised by Ian Archer in an important paper on philanthropy in early modern London. ${ }^{66}$ There, he suggests, charity may have become increasingly channelled through public institutions such as the livery companies, hospitals and the civil parish after the introduction of compulsory rating for the relief of 
the poor in $1572 .{ }^{67}$ In consequence the expenditure from endowed charities made by the Clothworkers, Grocers and Merchant Taylors' Companies between the 1590s and 1630s rose by factors of 3, 4 and 7 respectively, even if there is evidence of late-seventeenth century decline in the livery companies' charitable activities. ${ }^{68}$ Given the circumscribed range of trades officially open to women, almshouses founded by these companies were ever likely to include high proportions of men. In the northern Netherlands, however, such occupational almshouses were extremely rare, which may be a product of the comparatively weak position of the guilds there. Only in Utrecht could a few guilds boast a hospital for their elderly members. Their virtual absence in the Dutch Republic is therefore likely to provide at least a partial explanation for the differences in the gender balance between the two nations revealed in the late medieval and early modern data. ${ }^{69}$

Finally, we must return to the fundamental difference between the social welfare regimes in the two countries, which impacts upon the place of almshouses within the system of poor relief as a whole. The singularity of the centralised, statutory English poor relief system, administered by the parish, was noted above. ${ }^{70}$ While England was far from alone in passing legislation in the early modern period for statutory poor relief financed from taxation, it stood out in respect of the extent to which that legislation was put into practice, the widespread implementation of the system occurring either shortly before, or shortly after, the middle of the seventeenth century, the precise timing being the only fundamental issue remaining to be resolved. ${ }^{71}$ There was thus a much stronger connection between the parish and the almshouse than in the Dutch Republic. Here, throughout the Golden Age, there was no uniform, state-sponsored scheme of social welfare financed by an obligatory poor rate, for while some funds did indeed trickle down from local taxes and fines to assist the poor, private and voluntary donations provided the financial basis of the entire welfare system. ${ }^{72}$ There was apparently no need to statutorily enforce solidarity with the poor: indeed, numerous seventeenth-century visitors heaped praise upon the Dutch for the extent of their charitable giving, and at this date the Republic may have constituted Europe's most charitable nation in terms of per capita giving. ${ }^{73}$

It is, of course, possible to overdraw the contrast between the two countries. Charitable provision in England preceded the intervention of the Tudor state, and continued to assist the poor long after that intervention had taken place. In England and Wales a mixed economy of welfare developed during the later sixteenth and seventeenth centuries, and if the balance between private philanthropy and state welfare had shifted from the former to the latter as the seventeenth century drew to its close, the accumulated endowments from charitable giving over previous centuries remained substantial. ${ }^{74}$ Furthermore, the rise of associated philanthropy during the eighteenth century added a new means of raising larger funds for large-scale charitable projects, and from the end of that century the inspiration of evangelical Christianity in harness with the new political economy ensured that philanthropy remained a major contributor-possibly even the senior partner - in the mixed economy of welfare down to the third quarter of the nineteenth century. ${ }^{75}$ If the English system of social welfare was not, therefore, dominated by private provision in the manner of the Dutch, philanthropic activity remained of great significance throughout the period covered 
by this article, and almshouse foundations provide just one of the forms that this philanthropy took.

VI.

In view of the fundamentally different approaches to social welfare in the two countries that emerged during the sixteenth century, the similarities between the almshouses of England and the Dutch Republic might at first sight appear surprising. On reflection, however, there are a number of reasons to expect a degree of congruence. First, England and the Low Countries had a long history of association and intercourse. As early as the fourteenth century the Flemish weaving towns were already almost completely dependent upon England for their supplies of raw wool, while the burgeoning English cloth industry served to establish the London-Antwerp axis as its economic umbilical cord during the first half of the sixteenth century. As early as the twelfth century, but especially in the fourteenth century, immigrants from Flanders had been coming to England. They settled predominantly in London, but in a wide range of provincial centres too. While immigrants from Flanders formed a majority in the fourteenth century, by the fifteenth century the largest number came from Holland. Furthermore, although there is little evidence of permanent emigration from England to the continent, English merchants had been travelling there to trade and living in dedicated hostels since the thirteenth century, numerous English travellers and pilgrims passed through the region and aristocratic marriages facilitated the exchange of both artefacts and ideas. ${ }^{76}$ Trading links also encouraged cultural interaction, and the congruence between Dutch morality plays and urban pageants and those found in England is now fully recognised. ${ }^{77}$ As Caroline Barron writes, "There was contact and exchange between England and the Low Countries at every level." ${ }^{\text {78 }}$

With the onset of the Catholic Reformation (or Counter Reformation) in the mid sixteenth century, immigrants fled in their droves from Spanish persecution in the southern Netherlands, many gravitating towards the northern Netherlands, Germany and other destinations in continental Europe, but considerable numbers also finding their way across the North Sea to England. With the exception of the Moriscos expelled from Spain in 1609 and the Huguenots who fled Louis XIV's France during the 1680s, this was the largest uprooting experienced in early modern Europe, and their number has been estimated at a total of circa $180,000 .{ }^{79}$ Of these, perhaps 10,000 were to be found in England by the 1570s, the number peaking at approximately 15,000 in the 1590 s before falling back again to around 10,000 a generation later. ${ }^{80}$ Settling in London, Norwich, Colchester, Canterbury, Sandwich and other towns, largely in the south east and East Anglia, they made an enormous contribution to the industrial development of the English economy by imparting their skills, particularly in cloth production but in other trades too. ${ }^{81}$ Throughout the early modern age the Anglo-Dutch connection remained strong. And if the Dutch were sometimes resented in England for their economic success, and challenged on the seas as the English mercantile marine developed as serious opposition to the commercial hegemony of the Dutch, there can be no doubt that competition and admiration between the two nations co-existed during the seventeenth century, and that their relationship remained a close one. ${ }^{82}$ The Dutch 
Republic even employed English and (especially) Scottish troops, and was a haven for English exiles throughout the seventeenth century-explaining the presence of both Henry Hume and his uncle Sir John Conyers, the founding family of the Conyershuisjes on the island of Schouwen. ${ }^{83}$

Notwithstanding its radically different political structure, the United Provinces was a nation that was accessible to the English-historically, economically, culturally and geographically. When John Taylor, the Thames wherryman and self-appointed English "water poet," embarked on a journey from London to Prague in 1620, he arrived in The Hague on $26^{\text {th }}$ August, at Leiden on the $30^{\text {th }}$ and from there sailed to Amsterdam, where, he writes, "I saw many things worthy the noting, but because they are so neere and frequent to many of our Nation, I omit to relate them, to avoid tediousness ...." 84 Among the tediously familiar sights would have been the Dutch almshouses, described by the English ambassador to the Dutch Republic in the 1660 s as the "many and various Hospitals that are in every man's curiosity and talk that travels to their Countrey." ${ }^{\prime 25}$

A second factor explaining the similarity between English and Dutch almshouses is the common medieval religious heritage of the two nations, and the continuing incentive for good works implicit in Calvinism. The early injunctions for the monastic orders to provide for the poor and the needy were the edicts of European Catholicism, and charitable activity was particularly common among the Augustinian orders whose rule was able to accommodate the secular needs of the hospital. ${ }^{86}$ Even after the start of the transition to secular institutions, a regime of prayer was often imposed upon almshouse inmates to commemorate the founder, and to ensure his or her quick passage through purgatory. A particularly onerous regime was imposed at Ewelme in Oxfordshire, where the almsmen were daily required to say, inter alia, 189 Aves, 69 Pater Nosters and 15 Creeds. ${ }^{87}$ Thus while religious injunctions inspired both clerical and secular charitable giving in England from the early Middle Ages, the relationship between the religious and the secular was far from lost as the two forms of these institutions separated in practice. Similarly in the Netherlands, the first purpose-built almshouses had a religious as well as a social motive, again serving as a bedehouse to assist their founder's passage through purgatory. ${ }^{88}$ This particular aspect of almshouse communities seems to have persisted in many of those founded by Catholics, such as the St Paulushofje in the village of Etten, founded in 1681, the inhabitants of which were required every evening to pray for the soul of its founder Justus de Nobelaer. ${ }^{89}$

Even after the Protestant Reformation, with its emphasis upon the word rather than upon good works and its predestinarian theology, religious inspiration for charitable activity was far from lost. Although the theologically well-groomed Calvinist would realise that salvation was a gift from God and restricted to those He numbered among the Elect, founding an almshouse was for them more like a public assertion of their confidence in their salvation and an expression of their faith, a mark to distinguish the elect from the reprobate. ${ }^{90}$ For Dutch Mennonites, who were more theologically divided than the Calvinists, the founding of almshouses seems to have been inspired by the perceived need to balance material wealth, in principle a danger to the soul, with Christian love of one's neighbour. In England, furthermore, as well as in the Republic, theological sophistication was far from guaranteed and hence, as Ian 
Archer so succinctly put it, "Although the call for good works was articulated by the godly within a predestinarian framework, the strongly voluntarist language of the call to charity ... might well have been interpreted by the laity as indicating that their works would assist them in their passage to heaven." ${ }^{91}$ Notwithstanding the shift in theology, both in theory and in practice Catholics and Protestants shared similar attitudes towards the poor, as the continued charitable activity in countries such as England and the Dutch Republic so clearly testifies.

There were, of course, other common incentives. Rising population in the sixteenth century put pressure on employment and real wages in both countries, deepening the pool of those in need of assistance, particularly during periods of economic dislocation. The variety of essentially voluntary, locally-based forms of social welfare that developed in late medieval England finds distinct parallels in the Netherlands, providing a foundation for the decentralised system that emerged after the breakdown of the Catholic system of poor relief. ${ }^{92}$ In England too, the Reformation left a gaping hole in the existing system of social welfare, the size of which has been newly appreciated in recent research. ${ }^{93}$ A coherent system of state-sponsored provision took time to implement, and it may not have been until the second or even third quarter of the seventeenth century that it achieved anything approaching comprehensive coverage. In the meantime, private philanthropy stepped in to help fill the gap. ${ }^{94}$ In both countries the desire to memorialise one's life must also have loomed large, and finds reflection in the commemorative plaques with which many almshouses are adorned, celebrating both the foundation and the founder, while altruistic motiveswhile impossible to measure-should not be ignored either. For these reasons, and no doubt others besides, almshouses emerged to accommodate the elderly poor, with many common features, in both England and the United Provinces in the later medieval and early modern periods.

There are also potential explanations of the differences between almshouses in the two countries identified in section $\mathrm{V}$ above. With regard to the scarcity of rural almshouses in the United Provinces, and the far higher proportion found in England, the disparities in levels of urbanisation and urban structure in the two countries must surely have played a part. Even at the start of the sixteenth century, although it lacked one dominant city, the Netherlands included many more large towns than did England, as many as 12 having achieved a population of over 10,000 inhabitants compared with perhaps 5 in England. ${ }^{95}$ This contrast remained or was even enhanced 100 years later, when the Netherlands could boast 16 towns of this stature, which by now also included a major European city, while England included just six. ${ }^{96}$ Overall, therefore, the Netherlands was far more highly urbanised than England, and its urban sector generated a far higher proportion of its total national wealth than was the case in England. Furthermore, its centrifugal urban structure may have encouraged local endowments while the centripetal structure in England-so heavily dominated by London-may have had the opposite effect. London was such a magnet for migrants that a high proportion of its population had been born in the provinces. ${ }^{97}$ Those who achieved economic success there appear, in many instances at least, to have retained an emotional attachment to the place of their birth, and hence, when they died, significant numbers of rural villages were recipients of their largesse. W. K. Jordan, who waxed lyrical about the 
charitable contributions of the mercantile classes in general and of London merchants in particular, made special note of "the numerous almshouses founded by them in other counties," and this might help explain the superior numbers of rural endowments in England compared to the Dutch Republic. ${ }^{98}$

The greater prevalence of men in English almshouses, despite a demographic regime that favoured female over male longevity, might suggest that elderly women here were regarded as being more capable of maintaining their independence in old age. Indeed, based upon evidence from early modern Cratfield, Lynn Botelho has suggested that the reason that aged male pensioners were more likely to receive employment from the churchwardens reflects "their relative inability to provide for themselves." ${ }^{\prime 9}$ Richard Wall's analysis of a sample of five rural censuses dated between 1599 and 1796, along with the town of Lichfield in 1692 and Stoke in 1701, shows that only 2 per cent of males aged 65 plus lived alone in the pre-industrial English countryside, and only 3 per cent and 5 per cent respectively in Lichfield and Stoke. The figures for women, however, were significantly higher, at 16 per cent for the rural sample, and 15 and 8 per cent respectively in the two towns. ${ }^{100}$ Unfortunately, there are no comparable figures for household composition available for the Dutch Republic. It may be, however, that almshouses in the Netherlands concentrated on housing women precisely because women were expected to be able to look after themselves, unlike men. ${ }^{101}$ Some of the older almshouses for men would employ a maid to look after them. More importantly, however, the institution of old men's homes in many Dutch cities at the start of the seventeenth century seems to have taken care of this problem, correspondingly reducing their presence in almshouses.

Another reason for the gender contrast between English and Dutch almshouses may have been the fact that women in England, particularly elderly women, more commonly received poor relief in their own homes. This is evident, for example, in the earliest annual entry in the Colchester "Contribution to the Poor" book for 1582, where out of 114 individual payments for poor relief as many as 78 (68 per cent) were made to women apparently living on their own. ${ }^{102}$ Indeed, single women-predominantly widows or abandoned wives-feature prominently in all English early-modern urban relief lists analysed to date. ${ }^{103}$ In the rural listings that survive for the seventeenth and eighteenth centuries, women again form a clear majority. ${ }^{104}$ While this may, of course, reflect the greater vulnerability of elderly women to poverty-due to their longevity, lack of occupational opportunities, low rates of pay and more immediate responsibility for child care-it might also reflect a greater willingness on the part of parish officers to relieve women as opposed to men in their own homes, and thus impact upon the relative numbers of men and women found in almshouses. The absence of a statutory, rate-based system of outdoor relief in the Dutch Republic may have had the opposite effect, with a higher proportion of vulnerable women necessarily having to resort to institutional care.

\section{VII.}

So many features of almshouses in England and the Dutch republic, and the way in which they changed over time, deserve fuller exploration. The research described here identifies an enduring institution, one that persisted in the face 
of considerable intellectual, religious, economic and social change, and within the context of very different social welfare regimes. Despite the fact that England developed the most coherent and widely-enforced state welfare programme of any European state during the course of the later sixteenth and seventeenth centuries, private philanthropy was by no means supplanted and-in the parishes where they were founded-almshouses could provide accommodation for anywhere between 3 per cent and 23 per cent of the "at risk," elderly population. ${ }^{105}$ Preliminary estimates suggest a similar range in Dutch towns, but with little or no provision in the countryside. Despite a hardening of attitudes towards the "idle" or "dangerous" poor-a widely experienced phenomenon that arose in response to escalating social problems during the sixteenth centurythe "deserving" or "impotent" poor remained a valid object of care and concern, and the almshouse represents a degree of continuity between the medieval and early modern periods, while simultaneously its purpose became more clearly defined. ${ }^{106}$ In the Netherlands, however, while these institutions retained or even increased their significance over time, their relative contribution to the welfare of the elderly poor in England undoubtedly declined as state provision of outdoor relief first became more generalised, and then increased in generosity, during the second half of the seventeenth century.

These are, to repeat, preliminary conclusions, and it is hoped that the survey provided here will encourage further research, as well as highlighting features that deserve particular attention. We also hope that our attempt to provide a comparative perspective, and to offer some explanations of the many similarities and the key differences between almshouses in England and the Dutch Republic, will encourage further attempts at international comparison. Almshouses existed in many countries, certainly in those that border the Dutch Republic such as Belgium and Germany, and one might speculate that there may have been a north-western European model of almshouse provision, rather than one that was confined to the two countries surveyed here. ${ }^{107}$ There is already, however, evidence of regional variation within north-western Europe, for in Hesse the High Hospitals established in the sixteenth century by Landgrave Philipp the Magnanimous (1504-1567) were multifunctional care institutions, prioritising the elderly but increasingly taking in other categories among the poor, including the young and the sick, until they were transformed in the nineteenth century into medical hospitals. ${ }^{108}$ Similar institutions are in evidence in southern Europe too: certainly Italy and Spain were building hospitals in the early sixteenth century, many of which were of a cruciform design, allowing the combination of religious and secular needs by providing a range of buildings around a central courtyard. ${ }^{109}$ The Conyershuisjes introduced at the start of this article are not, therefore, just an enduring monument to the Anglo-Dutch couple who had them built, or just evidence of the strong links between England and the Dutch Republic: they also exemplify the multitude of similar institutions which studded the landscape of England, the Netherlands, and other parts of Europe as well. These institutions-particularly those designed specifically for the elderly-need further exploration across Europe, within the context of national, regional and local economic, social, religious and cultural contexts, but within a comparative framework too, for only this will provide a full appreciation of the role played by the almshouse in the welfare regimes of later medieval, early modern and, indeed, modern Europe. 


\section{Endnotes}

1. He had been governor of Berwick and the Tower of London. For the preceding see P. H. de Vos, De Grafschriften der voormalige St. Lievensmonsterkerk te Zierikzee (Zierikzee, 1911): 47-51.

2. N. Z. Davis, "Poor Relief, Humanism and Heresy," in Davis, Society and Culture in Early Modern France (London, 1975), chapter 2: 17-64.

3. Ibid., 46.

4. For example, P. M. Solar, "Poor Relief and English Economic Development before the Industrial Revolution," Economic History Review 48 (1995): 3.

5. E. van Nederveen Meerkerk, "The will to give. Charitable bequests by Dutch citizens, c. 1600-1800," unpublished paper delivered to the Eighth European Social Science History Conference, Ghent, 13-16 April 2010; see also M. Prak, "Armenzorg 1500-1800," in Studies over Zekerheidsarrangementen. Risico's, risicobestrijding en verzekeringen in Nederland vanaf de Middeleeuwen, ed. J. van Gerwen and M. H. D. van Leeuwen (Amsterdam/The Hague, 1998): 49-90.

6. The paucity of published work becomes clearer when one contrasts that available on philanthropy in general and almshouses in particular with the extensive historiography on the Old and New Poor Law. Some of the better general books on almshouses include: B. Bailey, Almshouses (London, 1988); B. Howson, Houses of Noble Poverty. A History of the English Almshouse (Sunbury-on-Thames, 1993); idem, Almshouses. A Social and Architectural History (Stroud, 2008). A valuable county survey is H. Caffrey, Almshouses in the West Riding of Yorkshire 1600-1900 (King's Lynn, 2006). The medieval period is better served: see, for example, N. Orme and M. Webster, The English Hospital 1070_ 1570 (New Haven and London, 1995) and S. Sweetinburgh, The Role of the Hospital in Medieval England. Gift-giving and the Spiritual Economy (Dublin, 2004). One of the best institutional studies is still J. Imray, The Charity of Richard Whittington. A History of the Trust Administered by the Mercers' Company 1424-1966 (London, 1968). For a recent general discussion see Goose, "The English Almshouse and the Mixed Economy of Welfare," and for a recent, academically-oriented, case study see N. Goose and L. Moden, A History of Doughty's Hospital, Norwich, 1687-2009 (Hatfield, 2010). For the continued vitality of the almshouse movement, see the website of the English Almshouse Association: www.almshouses.info.

7. In the Netherlands one is dependent on rather superficial overviews by, for example, D. P. M. Graswinckel, Nederlandsche Hofjes (Amsterdam, 1943), R. Lopes Cardozo, Hofjes in Nederland (Hilversum, 1977) and I. Dorren, Langs Hofjes: Routes in Nederland en België (Utrecht, 1994). More regional or local overviews in varying degrees of scholarship are available for the province of Friesland and the cities of Alkmaar, Amsterdam, Gouda and Haarlem: Peter Karstkarel and Leo van der Laan, Friese Hofjes. Gasthuizen, Diaconiehuizen en Armenhuizen (Leeuwarden, 2007); W. A. Fasel, A. Feld, L. F. M. Landzaat, and J. H. Rombach, "De Alkmaarse hofjes," Oud Alkmaar 7 (1983): 511-543; H. W. Alings, De Amsterdamse hofjes (Amsterdam, 1965); J. E. J. Geselschap, "Hofjes van Barmhartigheid," in Gouda zeven eeuwen stad, 1272-1972, ed. A. Scheygrond (Gouda, 1972): 219-240; G. H. Kurtz, Haarlemse Hofjes (Haarlem, 1972). There is only one study which treats with almshouses in a more profound manner, although with a heavy emphasis on architecture, and confined to the city of Leiden in the early modern age: H. M. Turck, Die Leidener Wohnstiftungen vom 15. bis 17. Jahrhundert (Aken, 1989). For the contemporary Dutch almshouse association see the Stichting Landelijk Hofjesberaad (www.hofjesberaad.nl). 
8. The English Almshouse Project, led by Nigel Goose, was established in 2006, and is a joint venture by the Family and Community Historical Research Society (FACHRS) and the Local Population Studies Society (LPSS), with a remit to attempt to create a gazetteer of almshouses in England Wales and to identify key features of their social, economic, administrative and architectural history. Similar neglect in the Dutch Republic has resulted in the establishment of a dedicated almshouse strand of the Giving in the Golden Age (GIGA) project, currently led by Marco Van Leeuwen at the International Institute of Social History in Amsterdam, with Henk Looijesteijn taking responsibility for the construction of a Dutch Almshouse Database (DAD), representing the larger gifts identified in the Republic.

9. Howson, Houses of Noble Poverty: 17; Sweetinburgh, Role of the Hospital: 21-23.

10. I. Leermakers and W. Donkersloot, Leidse hofjes. Wonen om Gods wille (Leiden, 2007): 8-9, 70; R. E. O. Ekkart, "De portretten in Meermansburg," Meermansburg. Leidens grootste hofje 1683-1983/De Leidse Hofjes 13 (1983): 13-39, there at 13.

11. J. Cooper (ed.), The Victoria History of the County of Essex, Vol. IX The Borough of Colchester (Oxford, 1994): 308.

12. C. M. Hogenstijn, De Verenigde Gestichten, Geschiedenis van Deventer gasthuizen en hun landerijen (Deventer, 1988): 43-45.

13. J. Broad, "Housing the Rural Poor in Southern England," Agricultural History Review 48: $151-170$.

14. They have not attracted much scholarly attention either. A famous example is the building of the Frans Hals Museum, which was founded specifically as an old men's home in 1606. Amsterdam's old women's home, founded in 1731, functioned as home for the elderly until a few years ago and now houses the Amsterdam dependance of the Hermitage Museum. Other old men's homes have been preserved in The Hague, Alkmaar, Breda, Goes, Gouda, Hoorn and Zaltbommel.

15. The National Archives, PROB 11, 45 Dixy, PCC will, John Hunwick, merchant and bailiff, 1594; Essex Record Office, Borough Muniments, Assembly Book 1576-99 [10 November, 1595, 3 September 1596]; Assembly Book 1620-46, f.176v [1637]; Assembly Book 1646-66, passim; British Parliamentary Papers, 1837-8, Vol. XXV.I, Report of the Commissioners for Inquiring Concerning Charities, $32^{\text {nd }}$ Report Part I, 552; J. Cooper (ed.), The Victoria History of the County of Essex (Oxford, 1994), Vol. 9: 369. In 1748 Morant noted that the interest on the $£ 300$ had been distributed to 1741 , although "it is sunk in proportion to the interest of other moneys": P. Morant, The History and Antiquities of ... Colchester, Book III (repr. Chichester, 1970, $1^{\text {st }}$ publ. London, 1748): 2.

16. P. D. de Vos, De voormalige kloosters en liefdadige instellingen te Zierikzee (Zierikzee, 1913): 92-94; Lopes Cardozo, Hofjes in Nederland: 135, 154.

17. Kurtz, Haarlemse Hofjes: 12. The same applied to the Heilige Drievuldigheidshuisjes in The Hague, founded in 1565 by Cornelis Barthout Jansz and the Hofje van Belois in Schiedam, founded in 1593 by Hubrecht Corssen: Lopes Cardozo, Hofjes in Nederland: 56; A. J. van de Ven, "De Hofjes van Belois," in Zuid-Holland. Tweemaandelijks orgaan van de Historisch Vereniging voor Zuid-Holland onder de zinspreuk "Vigilate Deo Confidentes" 13 (1967): 41-46; H. A. M. Roelants, "Het 'Hofje van Belois' te Schiedam," Algemeen Nederlandsch Familieblad V (1888): 102-105, Dorren, Langs hofjes: 88.

18. Goose and Moden, Doughty's Hospital: 33-34. Doughty's Hospital also provides an interesting example of an almshouse that was described interchangeably as a hospital and an almshouse, even in the will of its founder. 
19. Excluded from our remit remain those institutions, such as lazar houses or medical hospitals, specifically intended for the relief of the sick, although some almshouses might have a subsidiary nursing function. Also excluded are institutions established by local parish governors to relieve the poor, who might also function as homes for the elderly.

20. W. H. Godfrey, The English Almshouse (London, 1955): 20-44; E. Prescott, The English Medieval Hospital 1050-1640 (Melksham, 1992): 5-71; Howson, Almshouses: 77-91.

21. M.-C. Engels, Haagse gasthuizen door de eeuwen heen. Het Sint Nicolaasgasthuis, het Sacramentsgasthuis en het Oude Mannenhuis nader bekeken (The Hague, 2005): 29-31.

22. Godfrey, English Almshouse, 45-76; Prescott, English Medieval Hospital: 55-61, 77-86; Howson, Almshouses: 92-108.

23. Godfrey, English Almshouse: 58.

24. For this see especially, Graswinckel, Nederlandsche Hofjes, passim.

25. Prescott, English Medieval Hospital: 89-105; Caffrey, Almshouses: 27-33; Graswinckel, Nederlandsche Hofjes: 7-18.

26. R. M. Clay, The Medieval Hospitals of England (London, 1909): xvii-30; Godfrey, English Almshouse: 15-20; Howson, Houses of Noble Poverty: 17-33; Orme and Webster, English Hospital: 15-68. The best recent general survey can be found in Sweetinburgh, Role of the Hospital: 19-67.

27. For an accessible but authoritative modern account of the break with Rome, see J. Guy, Tudor England (Oxford, 1988), chapter 5: 116-153.

28. McIntosh, "Local Responses": 228.

29. We are most grateful to Marjorie McIntosh for allowing us to cite her unpublished estimates, which were presented at a conference entitled English Almshouses Revisited held at the University of Hertfordshire's St Albans Campus, $7^{\text {th }}$ March 2009. It must be emphasised that these are preliminary figures, which will be published in due course in a book on assistance to the poor in England 1350-1600, and where a detailed description of the methodology used to generate these numbers will be provided.

30. There is a substantial historiography on Dutch commercial success. The best overview is J. de Vries and Ad van der Woude, The First Modern Economy: Success, Failure, and Perseverance of the Dutch Economy, 1500-1815 (Cambridge, 1997).

31. W. K. Jordan, Philanthropy in England 1480-1660. A Study of the Changing Pattern of English Social Aspirations (New York, 1959): 27, 261-262.

32. Out of the 425 almshouses founded in the Netherlands before 1800 , the date of foundation of 104 remains unknown.

33. Bailey, Almshouses: 15-16; Howson, Almshouses: 59.

34. Based upon a comprehensive analysis of the Charity Commissioners' Digests of Endowed Charities, which related to the period 1861-75. The results of this study will be published in due course.

35. Of the 458 in Jordan's late medieval and early modern sample, as many as 71 lacked a stock for maintenance, and hence their continuance was far from guaranteed; Jordan, Philanthropy: 261-262. Almshouses lacking an endowment for maintenance have been excluded in the estimates of national totals offered above.

36. Imray, Charity of Richard Whittington: 10-12; Bailey, Almshouses: 48. 
37. William Doughty, who endowed the almshouse that bears his name in Norwich, had no children, but in his will took pains to justify the disposition of so much of his wealth in charitable deeds rather than leaving it to his more distant relatives, who had apparently dealt deviously with him in the past: Goose and Moden, Doughty's Hospital: 28-29. For an indication that those leaving larger endowments in London tended to be childless see I. Archer, The History of the Haberdashers' Company (Chichester, 1991): 72-74; R. Grassby, Kinship and Capitalism, Family and Business in the English Speaking World, 1580-1740 (Cambridge, 2001): 260-262, 399-400. See also L. McGranahan, "The Widow's Offering: Inheritance, Family Structure, and the Charitable Gifts of Women," Explorations in Economic History 46 (2009): 356-367.

38. Orme and Webster, English Hospital: 36-37; Bailey, Almshouses: 24. Examples of almshouses designed to accommodate the lucky number 13 are the almshouse founded in London by Richard Whittington, which was to include 13 poor folk, one of whom was to act as a tutor, England's oldest almshouse, St Cross in Winchester, founded in 1132, and Ewelme almshouse in Oxfordshire: Imray, Charity of Richard Whittington: 31; P. Hopewell, Saint Cross. England's Oldest Almshouse (Chichester, 1995): 3-4; C. Richmond, "Victorian Values in Fifteenth-century England: The Ewelme Almshouse Statutes," in Pragmatic Utopias: Ideas and Communities, 1200-1630, ed. R. Horrox and S. R. Jones (Cambridge, 2001): 226.

39. T. Murdoch and R. Vigne, The French Hospital in England. Its Huguenot History and Collections (Cambridge, 2009): 21; Bailey, Almshouses: 131-132.

40. Orme and Webster, English Hospital: 112-114.

41. Howson, Houses of Noble Poverty: 27; Sweetinburgh, Role of the Hospital: 27. Despite official ecclesiastical approval the practice continued through the fourteenth and fifteenth centuries.

42. Imray, Charity of Richard Whittington: 12.

43. Richmond, "Victorian Values": 227-228.

44. N. Goose and S. Basten, "Almshouse Residency in Nineteenth Century England: An Interim Report," Family Eु Community History 12 (2009): 73.

45. A. Langley, "Warwickshire Almshouses, 1400 to 1900: 'Affording Comfortable Asylums to the Aged and Respectable Poor?"' Warwickshire History XIV (2009/10): 148.

46. Goose and Basten, "Almshouse Residency": 70. At Higham Ferrers (founded 1423), the age of 50 was stipulated, and at Alkmonton (planned 1474) the age of 55: Orme and Webster, English Hospital: 112.

47. Norwich Record Office, Case 20f/14, William Doughty's Will, 25 ${ }^{\text {th }}$ April 1687; N/CCH 110, $24^{\text {th }}$ December 1856.

48. McIntosh, "Local Responses": 213-225.

49. See above, p. 7.

50. C. Leivers, "Housing the Elderly in Nineteenth-century Derbyshire: A Comparison of Almshouse and Workhouse Provision," Local Population Studies 83 (2009): 60, 64.

51. Graswinckel, Nederlandsche hofjes: 80; Dorren, Langs hofjes: 88-89; Lopez Cardozo, Hofjes in Nederland: 136.

52. See p. 4.

53. Goose and Moden, History of Doughty's Hospital: 33-34, 60-61.

54. Orme and Webster, English Hospital: 116-117; Archiefinventaris HCO. 
55. As happened in the Provenhuis Paling en Van Foreest in Alkmaar; where all regents had to descend from the founders. By 1686 only two lines of descendants were represented in the board, the Catholic family Ramp and the Dutch Reformed magisterial family Van Foreest, which incidentally did nothing to change the largely Catholic signature of this almshouse. That changed with the fleeing from France of a third line of more hard-line Calvinists, the Van Oudshoorn van Sonnevelt, who successfully claimed a position in the board despite opposition of the other lines. Their attempt to change the Catholic character of the almshouse failed however: Th. P. H. Wortel, Inventaris van het Provenhuis Paling en Van Foreest (Alkmaar, 1961): 9-13, 17, 21, 51-53.

56. 25 H. W. Alings, De Amsterdamse Hofjes (Amsterdam, 1965).

57. To wit, Dronrijp, Etten, Jutphaas, Marssum, Naaldwijk, Noordgouwe, Oosterland, Roosendaal, Swichum, Wergea and Wormerveer.

58. As was the case with both the founders of the rural almshouses of Schouwen, Sir John Conyers and Susanna Maria Lonque, who would typically spend much time in Zierikzee. Conyers was buried there, but Lonque preferred burial in the lordship where she founded her almshouse; P. H. de Vos, De Grafschriften der voormalige St Lievensmonsterkerk te Zierikzee (Zierikzee, 1911): 47-51; J. H. Simmelink and H. Uil, "Susanna Maria Lonque (1699-1752), ambachtsvrouwe van Ooster-en Sirjansland," Kroniek van het Land van de Zeemeermin (Schouwen-Duiveland) 25 (2000): 36-64. In Friesland the same phenomenon is visible. To name just two examples, Leeuwarden-based jurist Henricus Popta (1635-1712) founded an almshouse in the village of Marssum; a century before the famous Brussels-based jurist Viglius van Aytta founded an almshouse in his native Swichum; Karstkarel and van der Laan, Friese Hofjes: 92-96, 126-127.

59. Of course, many market towns were themselves often very small, generally containing perhaps 600 to 1,000 permanent inhabitants, and would only take on a more urban appearance on the days upon which their markets were held: A. Everitt, "The Marketing of Agricultural Produce," in The Agrarian History of England and Wales, Vol. IV 1500-1640, ed. J. Thirsk (Cambridge, 1967): 478. We are again grateful to Professor McIntosh for permission to quote her as yet unpublished figures.

60. These calculations are part of the ongoing research based upon the Digests of Endowed Charities mentioned in note 30 above. In each of these counties 19-21 per cent of localities included at least one almshouse, compared with a national average of 12 per cent.

61. Occasionally charity was extended to younger unmarried women or poor families, but children are relatively rarely found, and these institutions should be disregarded as they fall outside of the definition of an almshouse adopted here: above, p. 4.

62. Goose and Basten, “Almshouse Residency”: 69-70.

63. Orme and Webster, English Hospital: 115.

64. See above, p. 9.

65. Orme and Webster, English Hospital: 116. See also Imray, Charity of Richard Whittington: 10-12; Bailey, Almshouses: 48.

66. I. Archer, "The Charity of Early Modern Londoners," Transactions of the Royal Historical Society 12 (2002): 223-244.

67. Ibid.: 231-232.

68. Archer, "Charity": 236-238. 
69. A very few almshouses in the Netherlands housed widows of certain occupational groups, for example the Conyershuisjes: Sir John Conyers and Maria de Pottere assigned their almshouse to poor widows of physicians, ministers and officers: Dorren, Langs hofjes: 140-141; Lopes Cardozo, Hofjes in Nederland: 137.

70. See p. 2.

71. P. Slack, Poverty and Policy in Tudor and Stuart England (London, 1988): 170; S. Hindle, The Birthpangs of Welfare: Poor Relief and Parish Governance in Seventeenth-century Warwickshire, Dugdale Society Occasional Paper, 40 (2000); S. Hindle, On the Parish? The Micro-Politics of Poor Relief in Rural England c. 1550-1750 (Oxford, 2004): 246, 251.

72. Van Nederveen Meerkerk, "The Will to Give"; see also Prak, "Armenzorg 1500-1800," passim.

73. P. H. Lindert, Growing Public. Social Spending and Economic Growth since the Eighteenth Century. Vol. I. The Story (Cambridge, 2004): 7-8, 43, 46-47; P. Lindert, "Poor Relief before the Welfare State: Britain versus the Continent, 1780-1880," European Review of Economic History 2 (1998): 101-140.

74. Slack, Poverty and Policy: 170-172; N. Goose, "The Rise and Decline of Philanthropy in Early Modern Colchester: The Unacceptable Face of Mercantilism?," Social History 31 (2006): 469-487.

75. D. Owen, English Philanthropy 1660-1960 (Cambridge, Mass., 1964): 11-96; D. T. Andrew, Philanthropy and Police: London Charity in the Eighteenth Century (Princeton, 1989); A. Kidd, State, Society and the Poor in Nineteenth-century England (Basingstoke, 1999): 65-74; N. Goose, "The English Almshouse and the Mixed Economy of Welfare: Medieval to Modern," The Local Historian 40/1 (2010): 11-13.

76. C. Barron, "Introduction: England and the Low Countries 1327-1477," in England and the Low Countries in the late Middle Ages, ed. C. Barron and N. Saul (New York, 1995): 3-14; V. Harding, "Cross-channel Trade and Cultural Contacts: London and the Low Countries in the Later Fourteenth Century," in England and the Low Countries, ed. Barron and Saul: 153-168; D. C. Coleman, The Economy of England 1450-1750 (Oxford, 1977): 48-55.

77. A. F. Johnston, "Traders and Playmakers: English Guildsmen and the Low Countries," in England and the Low Countries, ed. Barron and Saul: 99-114.

78. Barron, "Introduction": 14.

79. This estimate is from J. A. Van Houtte, An Economic History of the Low Countries, 800-1800 (London, 1977): 135. The start of the large, religiously inspired waves of migration can be dated to the 1540s when the Counter-Reformation got underway: A. Pettegree, "Protestant Migration during the Early Modern Period," in Le Migrazioni in Europa secc. XIII-XVIII, Instituto Internazionale di Storia Economica "F. Datini," Prato, Serie II (1994): 441-458. Gwynn estimates 180,000-190,000 Huguenots left France in the late 1670s and 1680s, although others have suggested higher figures: R. Gwynn, Huguenot Heritage. The History and Contribution of the Huguenots in Britain $\left(2^{\text {nd }}\right.$ ed, Brighton, 2001, $1^{\text {st }}$ publ. 1985): 29-31.

80. Gwynn, Huguenot Heritage: 39-41. For a fuller discussion of their numbers in England see N. Goose, "Immigrants in Tudor and Early Stuart England," in Immigrants in Tudor and early Stuart England, ed. N. Goose and L. Luu (Brighton, 2005): 1-38. 
81. N. Goose, "Immigrants and English Economic Development in the Sixteenth and Early Seventeenth Centuries," in Immigrants in Tudor and Early Stuart England, ed. Goose and Luu: 136-160.

82. See for a recent assessment of Anglo-Dutch relations, L. Jardine, Going Dutch: how England Plundered Holland's Glory (New York, 2008).

83. See for these regiments F. J. G. ten Raa and F. de Bas, Het Staatsche Leger (Breda 1911-1964; 11 vols.); the Republic as a haven of English exiles: Jonathan Scott, England's Troubles: Seventeenth-Century English Political Instability in European Context (Cambridge, 2000). A valuable, recently published, collection of essays on this topicthough light on English examples-is, British and Irish Emigrants and Exiles in Europe, 1603-1688, ed. D. Worthington (Leiden and Boston, 2010).

84. J. Taylor, All the Works of John Taylor the Water-poet (London, 1630): 93 (third series of pagination).

85. Sir William Temple, Observations upon the United Provinces of the Netherlands ( $2^{\text {nd }}$ ed, London, 1673): 170-171. For other similar observations, see also Bailey, Almshouses: 119.

86. Prescott, English Medieval Hospital: 7; Orme and Webster, English Hospital: 70-72.

87. Richmond, "Victorian Values": 226.

88. Turck, Die Leidener wohnstifungen, passim.

89. H. G. J. Buijks et al., "Ten behoeve van dertien arme vrouwen" (Etten-Leur, 1981).

90. P. Lake, The Boxmaker's Revenge: "Orthodoxy," "Heterodoxy," and the Politics of the Parish in Early Stuart London (Manchester, 2001): 20-48; Archer, "Charity of Early Modern Londoners": 229.

91. Archer, "Charity of Early Modern Londoners": 229.

92. Van Nederveen Meerkerk, "The Will to Give."

93. N. S. Rushton, "Monastic Charitable Provision in Tudor England: Quantifying and Qualifying Poor Relief in the Early Sixteenth Century," Continuity and Change 16 (2001): 9-44; N. S. Rushton and W. Sigle-Rushton, "Monastic Poor Relief in Sixteenth-century England," Journal of Interdisciplinary History 32 (2001): 193-216.

94. For quantification of the philanthropic contribution see Jordan, Philanthropy in England; W. G. Bittle and R. T. Lane, "Inflation and Philanthropy in England: A Reassessment of W. K. Jordan's Data," Economic History Review 29 (1976): 203-210; J. F. Hadwin, "Deflating Philanthropy," Economic History Review 31 (1978): 105-117.

95. A. Cowan, Urban Europe 1500-1700 (London, 1998), Table 1.1: 7, based upon the figures presented by J. de Vries in his European Urbanisation 1500-1800 (London, 1984). The is some debate concerning the number of towns of this size in England, and one of the present authors (Nigel Goose) would suggest a lower figure, which would enhance the contrast.

96. Ibid.

97. See, for example, E. A. Wrigley, "A Simple Model of London's Importance in Changing English Society and Economy, 1650-1750," reprinted in Wrigley, People, Cities and Wealth: The Transformation of Traditional Society (Oxford, 1987): 133-156.

98. Jordan, Philanthropy: 262.

99. L. A. Botelho, Old Age and the English Poor Law, 1500-1700 (Woodbridge, 2004): 130; and see also p. 112. 
100. R. Wall, "Elderly Persons and Members of Their Households in England and Wales from Preindustrial Times to the Present," in Aging in the Past: Demography, Society and Old Age, ed. D. I. Kertzer and P. Laslett (California, 1995): 81-106, and Table 2.2.

101. Graswinckel, Nederlandsche Hofjes: 8. That sentiment served as argument for, for example, Willem Joseph van Brienen to set aside his parents' decision to found an almshouse for elderly men, who had apparently set one up because most almshouses in Amsterdam increasingly only accepted women and there was therefore a need for one only for men. Van Brienen however had found out by experience that it did not work that way as single men turned out to be unable to look after themselves; P. J. Margry (ed.), Hofje van Brienen. Twee Eeuwen Amsterdams Hofjesleven (Amsterdam/Hilversum, 1997): 36.

102. Essex Record Office, Accession C1 (part): Colchester Contribution Book to the Poor.

103. Slack, Poverty and Policy, Table 3: 75.

104. Hindle, On the Parish?: 274; T. Wales, "Poverty, Poor Relief and the Life-cycle: Some Evidence from Seventeenth-century Norfolk," in Land, Kinship and Life-cycle, ed. R. M. Smith (Cambridge, 1984): 351-404; W. Newman Brown, "The Receipt of Poor Relief and Family Situation: Aldenham, Hertfordshire 1630-90," in ibid.: 405-422; S. R. Ottaway, The Decline of Life: Old Age in Eighteenth-century England (Cambridge, 2004): 179-180; J. E. Smith, "Widowhood and Ageing in Traditional Society," Ageing and Society 4 (1984): 429-449. See, however, Botelho, Old Age: 112-113, for some contrasting evidence from the two English communities of Cratfield and Poslingford. See also S. Williams, Poverty, Welfare and Life-course Under the English Poor Law, 1760-1834 (Boydell Press, forthcoming), chapter 4.

105. I. W. Archer, "Hospitals in Sixteenth- and Seventeenth-century England," in Hospitals and Institutional Care in Medieval and Early Modern Europe, ed. M. Scheutz, A. Sommerlechner, H. Weigl and A. S. Weiss (2008), Table 4, p. 65. The proportion of the national population so relieved was, of course, much lower, standing at between 1.40-2.24 per cent in the later seventeenth century: Goose, "The English Almshouse," 8.

106. Davis, "Poor Relief, Humanism, and Heresy": 39, 46-51.

107. Germany, for example, shows a similar increase in foundations to that evident in fifteenth-century England: F. Hatje, "Comment: European Almshouses," Eighth European Social Science History Conference, Ghent, 13-16 April 2010.

108. C. Vanja, "Hospitals and the Care for the Elderly in Hesse, 1500-1800," unpublished paper delivered to the Eighth European Social Science History Conference, Ghent, 13-16 April 2010.

109. Howson, Houses of Noble Poverty: 51. 